\title{
Effects of Unconscious Emotional Distracters on Conscious Working Memory Maintenance in Patients with Posttraumatic Stress Disorder and Early Childhood Trauma: A Preliminary Functional Magnetic Resonance Imaging Study
}

\author{
Zoon-Sun Um, ${ }^{1}$ Jong-Chul Yang, ${ }^{1,2}$ Jong-II Park, ${ }^{1,2}$ and Gwang-Won Kim ${ }^{3}$ \\ ${ }^{1}$ Department of Psychiatry, Chonbuk National University Medical School, Jeonju, Korea \\ ${ }^{2}$ Research Institute of Clinical Medicine of Chonbuk National University-Biomedical Research Institute \\ of Chonbuk National University Hospital, Jeonju, Korea \\ ${ }^{3}$ Department of Psychiatry, Massachusetts General Hospital, Boston, MA, USA
}

유년기 정신적 외상을 경험한 외상후 스트레스장애 환자에서 무의식적 감정 자극이 의식적 작업기억 수행에 미치는 영향에 관한 기능적 자기공명영상 연구

엄준선 ${ }^{1} \cdot$ 양종철 ${ }^{1,2} \cdot$ 박종일 ${ }^{1,2} \cdot$ 김광원 $^{3}$

전북대학교 의과대학 정신건강의학교실, ${ }^{1}$ 전북대학교병원 의생명연구원, ${ }^{2}$ 하버드의대 메사추세츠종합병원 정신과학교실

Objectives: Few studies have assessed the neural mechanisms of the effects of unconscious emotional distracter on cognition in posttraumatic stress disorder (PTSD) patients. Thus, this study used functional magnetic resonance imaging (fMRI) to investigate the effects of unconscious emotional distraction involving fear during conscious working memory (WM) maintenance in patients with PTSD. Methods: This study included 10 patients with PTSD and positive early trauma inventory diagnosed based on Diagnostic and Statistical Manual of Mental Disorders fourth edition-text revision criteria, and 10 matched healthy controls Event-related fMRI data were obtained while the participants performed a WM task (face recognition) with neutral and unconscious emotional distracters. Results: Patients with PTSD may have sought to maintain WM function during the presentation of task-irrelevant emotional distractors that induced interruption and required attention. Compared to healthy controls, the PTSD patients exhibited significantly increased activity in the superior frontal gyrus, middle frontal gyrus, superior temporal gyrus, middle temporal gyrus, and lingual gyrus in a delayed-response WM task when presented with unconscious emotional and fearful stimuli relative to neutral distracters. Conclusion: This study identified specific brain areas associated with the interaction between emotional regulation and cognitive functioning during unconscious emotional distracters presented while patients with PTSD performed a WM maintenance task. There was no difference in brain activation between the two groups at the conscious level of neutral distractors, but under the unconscious emotional distracters, PTSD patients showed a specific activation of the brain.

Psychoanalysis 2019;30(4):114-123

KEY WORDS: Unconscious emotional distracter · Functional magnetic resonance imaging · Posttraumatic stress disorder Conscious working memory $\cdot$ Early trauma.

Received: September 3, 2019 Revised: September 19, 2019 Accepted: September 21, 2019

Address for correspondence: Jong-Chul Yang, MD, PhD

Department of Psychiatry, Chonbuk National University Medical School, 20 Geonji-ro, Deokjin-gu, Jeonju 54907, Korea

Tel: +82-63-250-2580, Fax: +82-63-275-3157, E-mail: yangjc@jbnu.ac.kr

서 론

많은 사람들이 외상을 겪고 이에 대한 정신적 충격을 받
으며, 이는 다양한 증상과 후유증을 유발한다. 이는 우울, 불

안과 같은 감정 반응은 물론이고 인지기능에 대한 영향도 매우 심한 것으로 알려져 있다(Watts 등 1988). 특히 과거에

This is an Open Access article distributed under the terms of the Creative Commons Attribution Non-Commercial License (https://creativecommons.org/licenses/by-nc/4.0) which permits unrestricted non-commercial use, distribution, and reproduction in any medium, provided the original work is properly cited. 
경험한 정신적 외상은 비슷한 상황 또는 유사한 충격적 자 극에 의해 심리적으로 반복 재경험하는 효과를 나타내기 때 문에 만성화 경향이 있고, 이는 오랫동안 인지기능을 비롯한 여러 후유증을 지속시키는 효과를 나타낸다(Phan 등 2004). 정신적 외상과 관련된 대표적 질환으로 외상후 스트레스장 애가 있으며 이 질환의 환자들에게 정신적 외상과 심리적 충격이 어떻게 작업 기억에 영향을 미치는지에 대한 대뇌 기전을 탐색한 연구는 거의 없다.

작업기억은 일시적으로 정보를 능동적으로 유지하고 조 작하며 처리하는 시스템이며, 사고, 계획, 추론, 의사 결정, 언 어 이해 등 고위 인지기능의 바탕이 된다(Baddeley와 Andrade 2000). 작업기억의 수행을 위해서는 억제 통제 기전(inhibitory control mechanism)이 같이 작동되어야 한다. 작업기 억의 억제 통제는 목표와 관련된 정보에 대해 주의 초점을 유지하면서 무관하거나 방해하는 정보를 무시하는 기전으 로서, 방해자극의 유해한 활동에 대해 반응 지연 동안 목표 와 관련된 기억을 보호하는 능력을 내포하는 집행기능의 일 종이다(Dolcos 등 2007). 작업기억과 작업기억의 억제 통제 기전에 대한 이해는 고위 인지기능의 기전을 이해하는 데 매우 중요한 단서를 제공한다(Curtis와 D’Esposito 2004). 심 리적 충격(psychic trauma)은 이러한 정보처리 과정에 영향 을 미치는 중요한 요인 중 하나이다(Martin 등 1995). 최근 신경영상학적 연구들을 통해 인지(cognition)와 정서(emotion)에 관여하는 뇌 영역들 간의 상호작용이 존재한다는 사 실이 밝혀졌다(Dolcos와 McCarthy 2006). 이는 정서가 인지 과정에 영향을 주기만 하는 일방향적 관계가 아니라 인지 과정 역시 정서에 영향을 미칠 수 있는 양방향적 관계임을 시사한다(Davidson과 Irwin 1999).

정신적 외상은 많은 심리적 문제를 일으키는데, 이러한 심 리적 문제들은 그 양상과 경과가 매우 다양하다(Horowitz 1986). 따라서 각 개인의 문제를 개별화하여 다루기 위해서 는 다양한 치료적 접근과 적용이 필요하다. 외상후 스트레스 장애 환자의 정신적 외상으로부터 초래된 심리적 문제를 이 해하고 다루기 위한 접근 방법 중 하나로 정신역동적 접근 이 있다. 환자의 정신구조 중 의식, 전의식과 더불어 무의식 적인 면을 함께 다루면서 현재의 행동은 외부에서 영향을 주고 있거나 그 사람 내부에서 작용하고 있는 모든 힘들의 상호작용이라는 것이다(Gillies 등 2013). 이렇게 정신적 외 상은 의식적인 영역뿐만 아니라 무의식적인 영역에까지 영 향을 준다. 따라서 정신적 외상이 심리에 끼치는 영향은 개 인과 환경 간의 상호작용, 그 개인의 정신적인 경험, 정신구 조 및 성격 등과 밀접한 관련성을 갖기 때문에, 이에 대한 심 도 있는 이해를 위해 정신역동적인 이해가 필요할 것이다
(Ablon과 Jones 1998), 그러나 몇몇 임상가들은 정신적 외상 을 겪은 사람들에게 정신역동적 접근을 하는 것은 개념이 다소 추상적이며, 치료의 효과를 객관적으로 입증하는 연구 가 많지 않다는 등의 이유로 기피하는 경향을 보이기도 하 였다. 이러한 경향에도 불구하고 외상후 스트레스장애 환자 의 치료에 있어서 심리 사회적 분야와 신경생물학적 분야가 융합된 통합 치료의 중요성이 점차 강조되고 있으며 특히, 무의식적 갈등이나 성격에 대한 영향이 많은 환자에게는 이 러한 정신역동적인 접근 방법이 적절하게 적용되는 것이 유 용할 것이다. 따라서 정신적 외상과 관련하여 무의식적인 감 정 자극이 의식적인 작업기억, 인지기능에 어떠한 영향을 주 는지 확인해 보는 것이 정신역동적인 접근과 신경생물학적 인 연결고리를 확인하는 데 도움이 될 것이다.

최근 기능적 자기공명영상(functional magnetic resonance imaging, fMRI)을 이용하여 작업기억에 관한 유사연구를 발 표하고 있으나 정상인들을 대상으로 한 연구들이 주로 이루 어졌고, 환자군을 대상으로 한 연구들은 부족한 실정이다 (Dolcos 등 2008).

따라서 본 연구에서는 유년기에 초기 정신적 외상의 경험 이 있으며 그 이후 심리적 충격 경험으로 인해 외상후 스트 레스장애를 진단받은 환자에서 정서적으로 불안을 유발하는 무의식적 감정 자극이 존재하는 경우 정상인과 다른 대뇌 부 위의 활성화를 나타낼 것이라고 가정하고, 기능적 자기공명 영상(fMRI)을 통해 외상후 스트레스장애 환자에서 불안을 유발하는 무의식적 자극을 처리하는 동안 활성화되는 대뇌 영역을 확인하였다. 또한 정서적으로 불안을 유발하는 자극 과 의식적인 인지기능을 담당하는 대뇌 영역 사이에 어떤 신경생리학적 관계가 존재하는지 연구하고자 하였다.

\section{대상 및 방법}

\section{실험 대상}

전북대학교병원 정신건강의학과 외래를 방문한 19 65세 의 환자 중 Diagnostic and Statistical Manual of Mental Disorders fourth edition-text revision(DSM-IV-TR)의 진 단 기준에 의해 외상후 스트레스장애를 진단받은 환자를 대 상으로 하였으며 환자들 중 19세 이전에 초기 정신적 외상 의 경험이 있었다고 응답한 early trauma inventory 양성 환 자들을 대상으로 선별하였다. 그 외에도 Edinburgh Handedness 검사에서 80점 이상으로 오른손잡이인 환자와 연구 의 목적을 이해하고 기능적 자기공명영상의 촬영 시 작업을 원활히 수행할 수 있는 인지적 능력을 갖춘 자[Mini-Mental State Examination(MMSE) 28.8 \pm 0.6 를 대상으로 선별하였 
Table 1. Characteristics of patients with PTSD and healthy controls

\begin{tabular}{lccc}
\hline \multicolumn{1}{c}{ Characteristic } & Patient with PTSD $(\mathrm{n}=10)$ & Healthy control $(\mathrm{n}=10)$ & $\mathrm{p}$-value \\
\hline Age (years) & $28.6 \pm 10.8$ & $29.1 \pm 10.8$ & $0.919^{*}$ \\
Sex (male/female) & $8 / 2$ & $8 / 2$ & $1.000^{\dagger}$ \\
Handedness (\% right) & 100 & 100 & $1.000^{\dagger}$ \\
Education (years) & $13.2 \pm 1.9$ & $13.0 \pm 1.6$ & $0.809^{*}$ \\
Duration of illness (months) & $43.5 \pm 14.1$ & - & - \\
MMSE & $28.8 \pm 0.6$ & - & - \\
CAPS & & & - \\
$\quad$ Total & $55.6 \pm 9.8$ & - & - \\
Months & $40.9 \pm 7.3$ & - & - \\
Weeks & $37.4 \pm 9.2$ & - & - \\
\hline
\end{tabular}

Values are presented as mean \pm standard deviation, number only, or \% right. *independent-samples t-test (Mann-Whitney U test), ${ }^{\dagger}$ chi-square test. PTSD: posttraumatic stress disorder, MMSE: Mini-Mental State Examination, CAPS: clinician administered PTSD scale

다(Oldfield 1971). 외상후 스트레스장애 외에 조현병, 주요 우울장애, 양극성 정동장애, 물질 관련 장애 등의 다른 주요 정신질환을 동반한 환자는 대상군에서 배제하였으며 또한, 의식 소실, 심장 질환, 신경학적 질환, 두부 손상의 과거력이 있는 경우, 체내 자기장에 영향을 미칠 수 있는 금속물질이 삽입되어 $\mathrm{MRI}$ 촬영이 불가능한 경우에도 대상자에서 제외하 였다. 이러한 기준을 바탕으로 본 연구에서는 외상후 스트레 스장애 환자 10 명이 선정되었다.

대조군으로는 19 65세의 일반 인구 대상 중, 정신건강의 학과 전문의 및 전공의에 의해 면담 시 주요 정신질환이 진 단(DSM-IV-TR)되지 않았고 정신과적, 신경학적 질환의 병 력이 없는 정상인 10 명으로 구성하였다. 모집된 환자군과 대 조군들은 나이, 성별, 교육에서 차이가 없었으며, 오른손잡이 만을 대상으로 하였다.

인구학적 변인으로 연령, 성별, 교육 기간 등을 평가하였 고, posttraumatic stress disorder(PTSD)에 대한 임상적 특성 으로 유병 기간을 조사하였다. PTSD의 증상 심각도는 clianician administered PTSD scale(CAPS)을 통해 평가되었다 (Table 1)(Blake 등 1995). 모든 PTSD 환자들은 항우울제 및 다른 향정신성 약물을 복용하고 있었다(Table 2). 또한 PTSD 환자군의 정신적 외상을 유형별로 분류하여 표로 제시하였다 (Table 3). 대상자들에게 연구와 관련된 모든 과정들은 상세하 게 설명한 후 서면 동의를 받았으며, 전북대학교병원 임상연 구윤리위원회(Institutional Review Board, IRB)의 승인(IRB No.: 2016-05-024)을 받았다.
Table 2. Psychotropic medications used by patients with posttraumatic stress disorder

\begin{tabular}{lc}
\hline Psychotropic medication & Range of daily dosage $(\mathrm{mg})$ \\
\hline Antidepressants & $10-20$ \\
Escitalopram $(\mathrm{n}=4)$ & $50-100$ \\
Desvenlafaxine $(\mathrm{n}=2)$ & $50-100$ \\
Sertraline $(\mathrm{n}=3)$ & 10 \\
Vortioxetine $(\mathrm{n}=1)$ & 15 \\
Mirtazapine $(\mathrm{n}=1)$ & 25 \\
Trazodone $(\mathrm{n}=1)$ & \\
Other medications & 0.5 \\
Clonazepam $(\mathrm{n}=1)$ & $0.25-0.5$ \\
Etizolam $(\mathrm{n}=3)$ & 0.25 \\
Alprazolam $(\mathrm{n}=1)$ & 12.5 \\
Zolpidem $(\mathrm{n}=1)$ & \\
\hline
\end{tabular}

Table 3. Psychologic trauma categories in patients with posttraumatic stress disorder

\begin{tabular}{cc}
\hline Type of psychologic trauma & $\mathrm{n}(\%)$ \\
\hline Sexual abuse & $1(10)$ \\
Bullying & $5(50)$ \\
Traffic accident & $3(30)$ \\
Natural disaster & $1(10)$ \\
\hline
\end{tabular}

\section{실험 방법}

\section{실험 자극}

모든 대상자들에게 fMRI을 촬영하면서 감정 자극과 함께 얼굴 사진 인식 과제를 수행하도록 하였다. 감정 자극 유형 으로는 불안 및 공포를 유발할 수 있는 사진으로 트라우마 관련 자극을 경험하도록 하였는데 상기 독립변수들은 사전 
예비 행동 실험을 통해 정확한 실험 조건을 결정하였다. 얼 굴 사진은 고등학교 졸업앨범에서 중립 표정을 하고 있는 얼굴들을 선택하였고, 남성과 여성이 반반씩 섞이도록 하였 다. 얼굴을 흑백으로 하여 얼굴의 눈, 코, 입, 눈썹 등만 보이 도록 타원형으로 사진을 재편집하였으며 한 시행 내에서 표 적 자극, 방해 자극 그리고 탐침 자극은 모두 같은 성별의 얼 굴 자극들로 구성하였다. 감정 자극 사진은 International Affective Picture System 및 웹사이트를 통해 자동차 사고, 자 연재해, 범죄, 테러 등의 주제와 연관된 50개의 감정 자극 사진 을 무선표집하여 구성하였다(Bradley와 Lang 2007). 또한 각 각의 사진들은 중복된 사진이 없도록 구성하였고, 이러한 사 진들의 광량은 조도계를 사용하여 동등하게 보정하였다. 중 성 자극(풍경, 꽃 등의 사진)은 상대적으로 감정 자극에 비해 기분을 좀 더 편안하게 만들 수 있는 사진으로 선별하여 제 시되었다.

\section{실험 자극 패러다임}

각 시행은 기억 단서(1초), 부호화 과정(표적 자극, 5초), 지연 기간(4초), 방해 자극(6초), 버튼 준비(2초), 인출 과정 (탐침 자극, 2초), 시행 간 간격(12초)으로 구성하였다(Figure 1). 각 시행마다 맨 처음 'face'를 지시하는 단어를 화면 정중앙에 기억 단서로서 1 초 동안 제시한다. 부호화 과정에 서는 5 초 동안 서로 다른 3 개의 얼굴 사진들을 한 장씩 보여 준다. 지연 기간에는 피험자로 하여금 부호화 과정에서 표적 자극으로 보여준 3 개의 정상적 얼굴 사진들을 기억 유지하 도록 한다. 이때 얼굴 사진들의 기억 유지를 방해하기 위하 여 정상인 얼굴 사진과 변형된 얼굴 사진들을 방해 자극으 로 제시한다. 방해 자극이 제시된 후 인출 과정에서는 이미 부호화 과정에서 제시했던 3개의 정상적 얼굴 사진들 또는 미제시 사진들 중에서 무작위로 선정한 1 개의 사진을 탐침 자극으로 2초 동안 제시한다. 이때 앞에서 보았던 표적 자극
얼굴 사진과 탐침 자극 얼굴 사진의 일치 여부를 판단하여 해당되는 마우스 버튼을 누르도록 한다. 오른손 버튼은 앞서 본 표적 자극과 일치한 경우, 왼손 버튼은 새로운 얼굴 사진 이 나타났을 때 누르도록 하며, 탐침 자극의 제시가 끝난 직 후 2초 이내에 신속하고 빠르게 반응하도록 요구한다.

본 연구에서는 총 20회 시행으로 구성하였으며, 그중 10회 시행은 정상적 얼굴 사진의 방해 자극이 제시되었고, 나머지 10 회 시행은 변형된 얼굴 사진들이 제시되었다. 총 20회 시 행에서 두 유형의 방해 자극들이 나오는 순서는 무작위로 배 열하였으며, 본 실험에 소요된 총 시간은 11 분 16 초였다. 한 편 총 20개 시행에서 표적 자극과 탐침 자극이 일치하는 시행 (10개 시행)과 일치하지 않는 시행(10개 시행)의 수를 동일하 게 하였다. 실험에 사용된 영상은 Superlab Pro(Cedrus Co., Los Angeles, CA, USA) 프로그램을 이용하여 제작하였으며 참가자들은 $\mathrm{MRI}$ 실 내부의 모니터를 통하여 두부 코일의 거 울에 비친 영상을 보도록 하였다. 본 실험에 참여하기 직전 참가자들은 20 30분 동안 실험 절차에 관한 설명을 듣고 연 습을 통해 실험에 사용될 과제를 숙지하도록 하였다.

\section{기능적 자기공명영상법(fMRI)}

기능적 자기공명영상을 얻기 위해서 3.0T MAGNETOM Verio MR Scanner(Siemens Healthineers, Erlangen, Germany)와 12 채널 두부 코일(head coil)을 사용하였다. 영상 을 얻기 위한 펄스 파형은 경사에코(gradient-echo) 영상 기 법(echo plannar imaging, EPI)을 사용하였으며, 영상 변수로 는 반복 시간(repetition time, TR)/에코 시간(echo time, $\mathrm{TE})=2,000 / 30 \mathrm{msec}$, 숙임각(flip angle) $=90^{\circ}$, 영상 영역(field of view, FOV) $=22 \times 22 \mathrm{~cm}$, matrix 크기 $=64 \times 64$, 여기 횟수 (number of excitation, $\mathrm{NEX}$ ) 1 , 절편 두께 (slice thickness) $=5$ $\mathrm{mm}$ 로 하였다. 이때 전교련(anterior commissure, $\mathrm{AC}$ )과 후 교련(posterior commissure, $\mathrm{PC}$ )을 연장한 $\mathrm{AC}-\mathrm{PC}$ line을 기

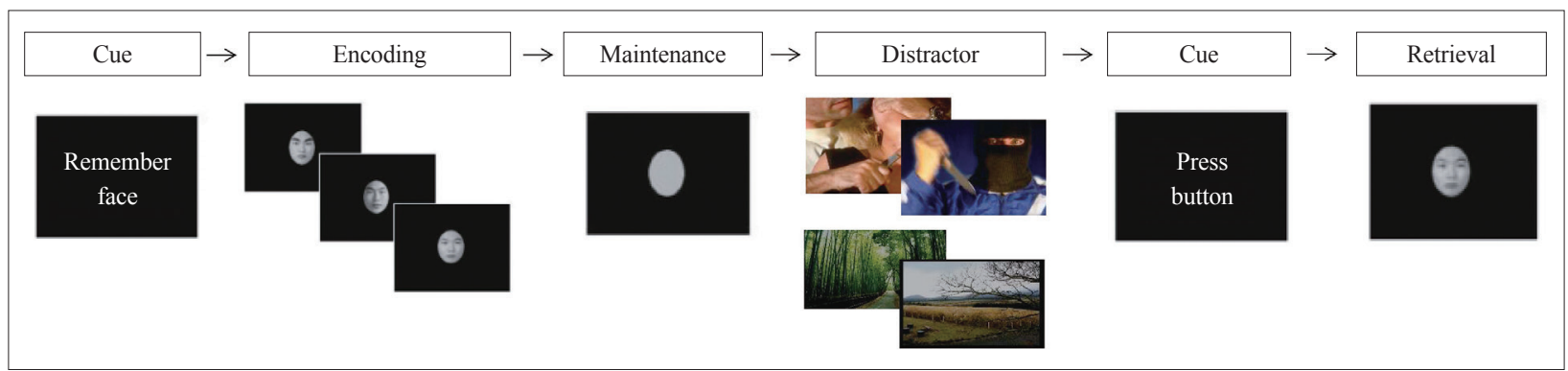

Figure 1. Diagrams of the delayed-response WM tasks with emotional and neutral distractors. In the encoding task, three different human faces appeared once. The subjects were instructed to encode and maintain the WM for the presented human face, followed by looking at the distracters with neutral pictures (or trauma-provoking and emotional pictures) while maintaining the WM. During the retrieval period, either the face presented in the encoding task or a new face was presented (50\% were presented with an encoding face and $50 \%$ were presented with a new face), and then the response to the probe for the previously presented human face or the new face was recorded. WM: working memory. 
준으로 하여 25 개의 횡단면으로부터 fMRI 영상을 얻었다. EPI 영상이 평형 상태를 이루기 전에 나타나는 높은 신호를 보정하기 위해 4초 동안 2 phase의 모조 영상(dummy scan) 을 추가로 얻었다.

\section{자기공명영상법(MRI)}

고해상도의 T1강조영상을 얻기 위하여 3.0T MAGNETOM Verio MR Scanner를 사용하였다(Hasegawa 등 2013). $\mathrm{T} 1$ 강조영상은 TR/TE=1,900/2.35 msec를 사용하여 시상면 방향으로 영상을 획득하였다. 이때 사용된 $\mathrm{FOV}$ 는 $22 \times 22$ $\mathrm{cm}$, matrix의 크기는 $256 \times 256$, NEX는 1 , slice thickness는 $5 \mathrm{~mm}$ 로 하였고 총 영상 획득 시간은 193초였다.

\section{영상의 후처리 및 분석}

\section{대뇌 활성화 지도(Brain activation map)}

대뇌의 활성화 지도를 얻기 위하여 MATLAB(Mathworks, Inc., Natick, MA, USA) 환경에서 구현되는 SPM8(Statistical Parametric Mapping 8, The Wellcome Center for Human Neuroimaging, University College London, London, UK) 프로그램을 이용하였다. 먼저 기초 영상 자료들은 머리의 움 직임으로 인해서 생기는 잡음을 보정하기 위해 움직임 보정 (motion correction)과 재정렬(realignment)의 절차를 거친 다음, SPM8에서 제공하는 EPI template에 공간적 표준화 (spatial normalization)를 수행하였다. 표준화된 영상은 신호 대 잡음비(signal to noise ratio)를 높이기 위해 $8 \mathrm{~mm}$ 의 full width at half maximum을 갖는 Gaussian kernel filter로 중 첩(convolution)하여 편평화(smoothing)하였다.

정상인과 외상후 스트레스장애 환자들을 대상으로 수행 한 그룹 내 분석에서는 'paired t-test $(\mathrm{p}<0.001)$ '를 이용하여 감정 자극 대비 중성 자극에 의한 활성화 영상을 얻었으며 t-value 결과는 각 영역에서 가장 높은 수치를 명시하였다. 또한 peak p-value 기준으로 t-value를 산출하고 해당 voxel 이 위치한 brain regions를 atlas에서 확인하여 영역을 한정 하였다(Kim 등 2015). 이후 외상후 스트레스장애 환자군과 정상 대조군 사이 그룹 간 활성화 차이 영상은 피검자 개인 별 시각 자극에 의한 활성화 영상을 기초로 하여 SPM8상에 서 그룹 분석 도구인 'two sample t-test( $\mathrm{p}<0.001)$ '를 이용하 였다. 두 그룹 간에서 유의한 차이를 보이는 복셀의 좌표는 $\mathrm{SPM}$ 의 표준 공간인 Montreal Neurological Institute 좌표를 이용하였다(Bergouignan 등 2009). 본 연구의 결과들은 탐 침 자극을 주었을 때 피험자들이 정확히 재인 판단(표적 자 극과 일치할 경우 오른손 버튼, 새로운 사진일 경우 왼손 버
튼)을 했던 데이터들을 이용하여 분석하였다.

\section{결 과}

\section{인구학적 및 임상적 특성 양상}

Table 1은 PTSD 환자군과 정상 대조군에서 인구학적 특 징 및 임상적인 특징을 보여주고 있다. PTSD 환자군과 정상 대조군 사이에 연령, 성비, 손잡이 방향, 교육 수준에서는 유 의미한 차이를 나타내지 않았으며 PTSD 환자군의 임상적 인 특징으로 유병 기간(43.5 \pm 14.1 months), CAPS score

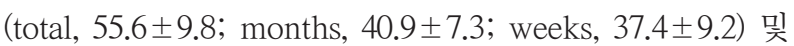
$\operatorname{MMSE}(28.8 \pm 0.6)$ 를 나타내었다(Table 1). fMRI를 촬영하 면서 무의식적인 감정 자극과 함께 얼굴 사진 인식 과제를 수행하도록 하였는데 중성 자극에 대한 과제 수행 정확도를 살펴볼 때 PTSD 환자군과 정상 대조군 사이에 유의미한 차 이를 나타내지 않았다 $(68 \pm 15.4 \%$ vs. $72 \pm 11.3 \%, \mathrm{p}=0.255)$. 그 러나 감정 자극에 대한 과제 수행 정확도를 살펴볼 때 PTSD 환자군에서 수행 정확도가 유의미하게 감소되는 모습을 확 인할 수 있었다 $(65 \pm 10.8 \%$ vs. $71 \pm 11.9 \%, \mathrm{p}=0.004)$. 중성 자 극 및 감정 자극에 대한 두 군의 반응 시간을 살펴보면 중성 자극에 대한 PTSD 환자군과 정상 대조군의 반응 시간에서는 PTSD 환자군에서 반응 시간이 지연되는 모습을 보였으며 $(1,424.4 \pm 302.2 \mathrm{~ms}$ vs. $1,213.0 \pm 222.6 \mathrm{~ms}, \mathrm{p}<0.001)$ 또한 감 정 자극에 대한 PTSD 환자군과 정상 대조군의 반응 시간에서 도 PTSD 환자군에서 반응 시간이 지연되는 모습을 확인할 수 있었다(1,502.1 $\pm 271.0 \mathrm{~ms}$ vs. $1,352.1 \pm 244.1 \mathrm{~ms}, \mathrm{p}<0.001)$. 결과적으로 정상 대조군에 비해 $\mathrm{PTSD}$ 환자군에서 중성 자극 및 감정 자극에 반응하여 작업기억 수행이 저하되었다.

\section{중성 자극 대비 감정 자극 시에 각 그룹 내 대뇌 활성화 부위}

fMRI 촬영 시 감정 자극 혹은 중성 자극을 제시하는 6초 의 지연 기간 동안 중성 자극 대비 감정 자극일 때 각 그룹 내에서 더 활성화되는 대뇌의 영역을 측정하였다. 정상 대조 군에서는 중측두이랑, 하측두이랑, 방추형이랑, 하후두이랑 에서 활성화를 나타내었으며 PTSD 환자군에서는 중측두이 랑, 모이랑, 중후두이랑에서 더 활성화되는 결과를 나타내었 다 $(\mathrm{p}<0.001)$ (Table 4, 5, Figure 2).

\section{감정 자극 및 중성 자극과 관련하여 각 그룹 간 대뇌 활성화 패턴의 차이}

감정 자극이 주어질 때에는 정상 대조군과 비교하여 PTSD 를 가진 환자군에서 상전두이랑, 중전두이랑, 보조 운동 영 역, 상측두이랑, 중측두이랑, 모서리위이랑, 모이랑, 상후두 
이랑, 혀이랑 영역에서 대뇌 활성화가 증가되었음을 확인할 수 있었다 $(\mathrm{p}<0.001)$ (Table 6, Figure 3). 이와 반대로 중성 자 극하에서는 정상 대조군과 PTSD 환자군 사이에 대뇌 활성 화 패턴에 차이를 나타내지 않았다.

Table 4. Brain activation regions in response to emotional distractor in healthy controls

\begin{tabular}{lcccc}
\hline \multirow{2}{*}{ Brain area } & \multicolumn{5}{c}{ Healthy controls } \\
\cline { 2 - 5 } & t-value & \multicolumn{3}{c}{ MNI coordinates } \\
\cline { 2 - 5 } & & & $\mathrm{x}$ & $\mathrm{z}$ \\
\hline Frontal lobe & - & - & - & - \\
Middle frontal gyrus & & & & \\
Temporal lobe & 3.98 & 44 & -71 & -5 \\
Middle temporal gyrus & 5.40 & -44 & -66 & -12 \\
Inferior temporal gyrus & 5.54 & -46 & -58 & -16 \\
Fusiform gyrus & & & & \\
Parietal lobe & - & - & - & - \\
Postcentral gyrus & - & - & - & - \\
Angular gyrus & & & & - \\
Occipital lobe & - & - & - & - \\
Middle occipital gyrus & 4.27 & 42 & -74 & -6 \\
Inferior occipital gyrus & &
\end{tabular}

Identified in brain areas showing activations response to the emotional relative to the neutral distractor $(\mathrm{p}<0.001)$. MNI: Montreal Neurological Institute

\section{고 찰}

현대심리학이나 인지과학은 백여 년간의 논쟁이 있었지만 지금은 무의식적 인지 과정의 존재를 인정하고 있다. 그러나 무의식적 감정 과정(unconscious affective process)에 대해

Table 5. Brain activation regions in response to emotional distractor in PTSD patients

\begin{tabular}{|c|c|c|c|c|}
\hline \multirow{3}{*}{ Brain area } & \multicolumn{4}{|c|}{ Patients with PTSD } \\
\hline & \multirow{2}{*}{ t-value } & \multicolumn{3}{|c|}{ MNI coordinates } \\
\hline & & $\mathrm{x}$ & $\mathrm{y}$ & $\mathrm{z}$ \\
\hline \multicolumn{5}{|l|}{ Frontal lobe } \\
\hline Middle frontal gyrus & - & - & - & - \\
\hline \multicolumn{5}{|l|}{ Temporal lobe } \\
\hline Middle temporal gyrus & 4.56 & 48 & -74 & 10 \\
\hline Inferior temporal gyrus & - & - & - & - \\
\hline Fusiform gyrus & - & - & - & - \\
\hline \multicolumn{5}{|l|}{ Parietal lobe } \\
\hline Postcentral gyrus & - & - & - & - \\
\hline Angular gyrus & 4.00 & -46 & -66 & 22 \\
\hline \multicolumn{5}{|l|}{ Occipital lobe } \\
\hline Middle occipital gyrus & 4.48 & 48 & -75 & 10 \\
\hline Inferior occipital gyrus & - & - & - & - \\
\hline
\end{tabular}

Identified in brain areas showing activations response to the emotional relative to the neutral distractor $(\mathrm{p}<0.001)$. PTSD: posttraumatic stress disorder, MNI: Montreal Neurological Institute
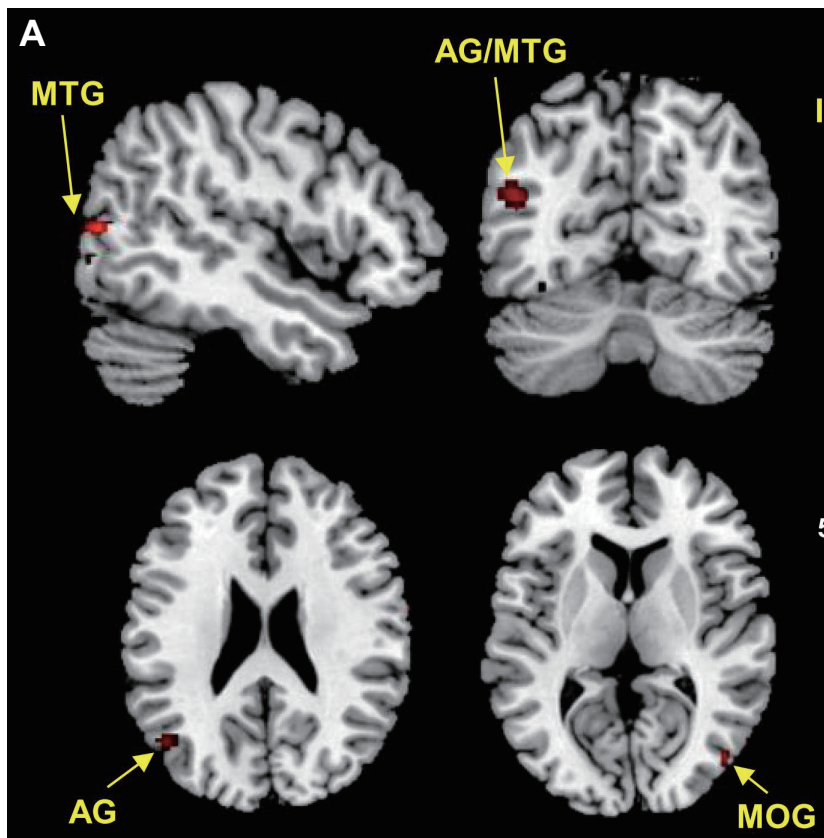

MOG

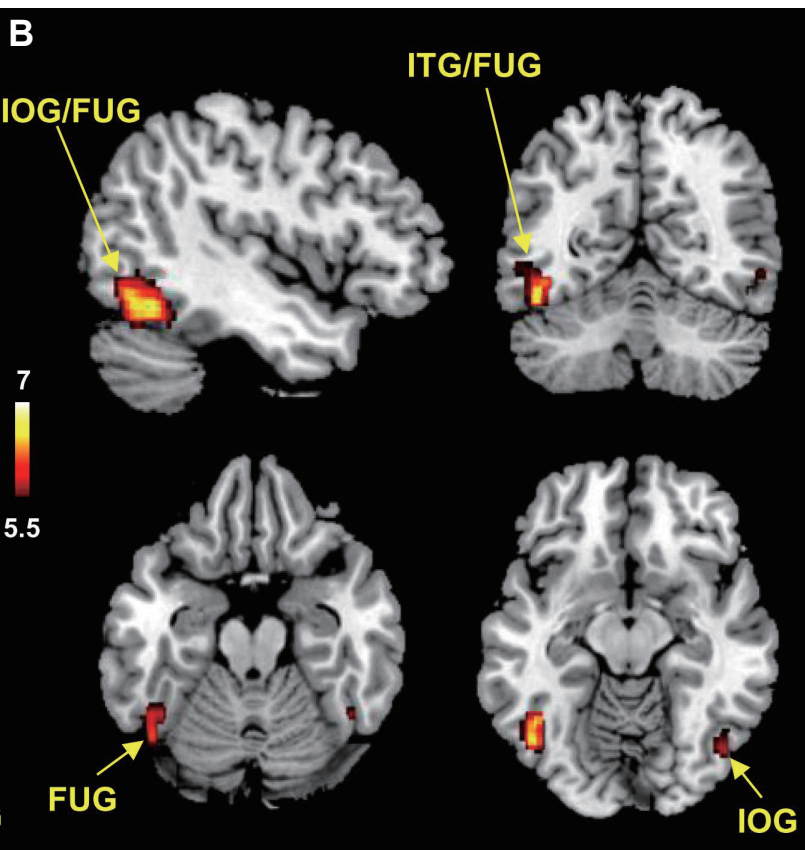

Figure 2. Brain regions predominantly showing increased activation to the emotional relative to the neutral distractor $(p<0.001)$. A: posttraumatic stress disorder patients. B: Healthy controls. MTG: middle temporal gyrus, AG: angular gyrus, MOG: middle occipital gyrus, IOG: inferior occipital gyrus, ITG: inferior temporal gyrus, FUG: fusiform gyrus. 
서는 아직 논란이 많다. 프로이트 자신도 감정이 무의식적일 수 있다는 사실에 회의적이었다. 그의 치료 기법이나 임상 보고는 이것을 잘 보여주는데도 자신은 이에 대해 확신하지 못하고 있었던 것이다. 그러나 1960년대 무의식적 감정 개념 이 정신분석 이론가들에 의해서 분명해졌으며 많은 연구들 이 밝혀낸 바에 의하면 일반적으로 감정 과정은 무의식에서 진행되며 불안이나 우울 등의 불쾌한 감정을 피하기 위해서

Table 6. Brain activation regions in response to emotional distractor between groups

\begin{tabular}{lrrrr}
\hline \multirow{2}{*}{ Brain area } & \multirow{2}{*}{ t-value } & \multicolumn{3}{c}{ MNI coordinates } \\
\cline { 3 - 5 } & & $\mathrm{x}$ & $\mathrm{y}$ & $\mathrm{z}$ \\
\hline PTSD patients>healthy controls & & & & \\
Superior frontal gyrus & 5.11 & 8 & 31 & 56 \\
Middle frontal gyrus & 4.21 & -36 & 30 & 36 \\
Supplementary motor area & 5.16 & 8 & 30 & 56 \\
Superior temporal gyrus & 4.52 & -60 & -55 & 23 \\
Middle temporal gyrus & 4.65 & -59 & -56 & 22 \\
Supramarginal gyrus & 4.34 & -58 & -55 & 25 \\
Angular gyrus & 4.62 & -58 & -58 & 24 \\
Superior occipital gyrus & 4.80 & -8 & -102 & 10 \\
Lingual gyrus & 4.22 & 6 & -78 & -4
\end{tabular}

Healthy controls $>$ PTSD patients

No significant difference in brain activation patterns

Identified in brain areas showing activations response to the emotional relative to the neutral distractor between groups (PTSD patients $>$ healthy controls $)(\mathrm{p}<0.001)$. MNI: Montreal Neurological Institute, PTSD: posttraumatic stress disorder
스스로 무의식적으로 방어한다고 한다(Westen 1999). 표면 적으로는 기억 및 작업 수행과 같은 의식적인 행동에 무의 식의 영향이 적을 것으로 생각되나 실제 많은 정신분석 이 론가와 그와 관련된 여러 연구들에서 무의식이 의식적인 작 업 수행에 많은 영향을 미치고 있다는 것을 보여주고 있다. 따라서 본 연구에서는 유년기에 초기 정신적 외상의 경험이 있으며 그 이후 심리적 트라우마(psychologic trauma) 로 인 해 PTSD를 겪고 있는 사람들을 대상으로, 트라우마와 관련 된 무의식적 감정 자극을 제시하여 불안과 같은 불쾌한 감 정이 유발된 상황하에 얼굴 인식에 관한 기억 과제를 수행 하도록 하고, 얼굴 인식에 대한 정확도 및 반응 시간을 확인 하였다. 또한 $\mathrm{fMRI}$ 를 이용하여 의식적 인지기능 과제 수행 과 연관된 대뇌 활성화 영역 및 정도를 탐색하였다.

얼굴 인식 과제의 정확도와 반응 시간에서는 정상 대조군 에 비해 PTSD 환자군에서 무의식적인 감정 자극이 방해 자 극으로 제시될 때 작업기억의 유지가 감소되는 것으로 나타 났다. 또한 중성 자극과 비교하여 무의식적 감정 자극에서 작업 수행의 정확도가 떨어지고 반응 시간도 지연된다는 것 을 확인해 볼 수 있었다. 이것은 PTSD 환자들이 목적과 연 관된 정보를 유지하고 목적과 관련 없는 정보들은 배제하려 고 하나 불안을 유발하는 상황이나 정신적 외상과 관련된 무의식적인 감정 자극이 관여될 때 이러한 수행이 적절히 이뤄지지 않음을 시사한다(D’Esposito 등 1999). 외상후 스 트레스장애 환자는 특히 성인기에 경험한 외상에 의해 압도 당할 수 있는데 어린 시절의 정신적 외상은 정서 발달(affec-

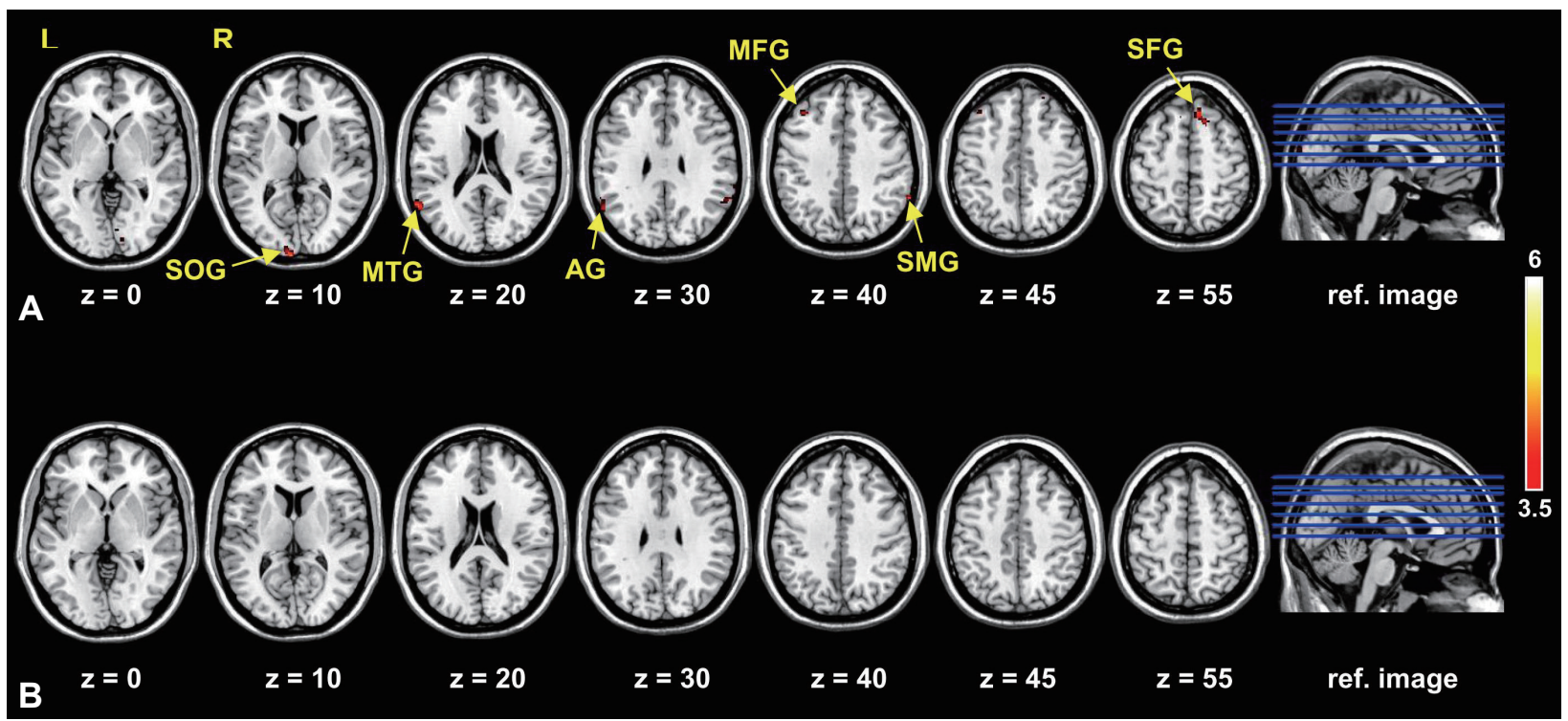

Figure 3. Brain regions predominantly showing increased activation to the emotional relative to the neutral distractor $(p<0.001)$. A: Emotional distractor; PTSD patients>healthy controls. B: Neutral distractor; healthy controls>PTSD patients. PTSD: posttraumatic stress disorder, SOG: superior occipital gyrus, MTG: middle temporal gyrus, AG: angular gyrus, MFG: middle frontal gyrus, SMG: supramarginal gyrus, SFG: superior frontal gyrus. 
tive development)에서 고착(arrest)을 가져오고, 성인기의 외 상은 퇴행(regression)을 가져온다고 한다(Krystal 1984). 따 라서 환자들은 생존을 위협받았던 유아기 자기(infantile self) 의 경험을 성인기의 정신적 외상과 연결시키거나 어린 시절 의 외상의 재활성화를 통해 정신 증상을 경험하게 되고 이러 한 정신적 외상과 연관된 감정 자극이 무의식적으로 작용하 여 작업기억, 암묵기억, 외현기억 등의 의식적인 기억 수행 에 어려움을 나타낼 수 있다. 얼굴 인식 과제에서 PTSD 환 자군에서의 반응 시간 지연과, 과제 수행 정확도가 감소된 결과를 통해 정신적 외상과 관련된 무의식적인 감정 자극이 외상을 재활성화시키고 실제 의식적인 작업 기억 등의 수행 기능을 감소시켰다는 것을 확인할 수 있었다.

$\mathrm{fMRI}$ 를 촬영하면서 감정 자극 및 중성 자극과 함께 얼굴 사진 인식 과제를 수행하도록 하였고 이에 따른 대뇌 활성 화 영역과 정도를 PTSD 환자군과 정상 대조군에서 확인해 보았다. 중성 자극에 비해 감정 자극하에 더 활성화되는 대 뇌의 영역에 정상 대조군은 중측두이랑, 하측두이랑, 방추형 이랑, 하후두이랑에서 활성화를 나타내었으며, PTSD 환자 군에서는 중측두이랑, 모이랑, 중후두이랑에서 더 활성화되 는 결과를 보였다. Schuff 등(2011)은 PTSD 환자 17명과 대 조군 15 명의 기능적 자기공명영상의 분석 결과 PTSD 환자 에서 오른쪽 상측두엽의 활성 증가를 보고하였으며 Hendler 등(2001)의 기능적 자기공명영상 연구에서는 PTSD 환자에 게 반복된 외상 자극 시 대조군보다 증가된 후두엽 활성을 보고하였다. 또한 Lanius 등(2002)은 해리 증상이 동반된 7 명의 PTSD 환자가 10 명의 외상 노출 대조군에 비해 기능 적 자기공명영상에서 오른쪽 상측두엽, 중측두엽 및 왼쪽 후 두엽의 활성 증가를 보인다고 하였다. PTSD를 대상으로 기 능적 자기공명영상을 연구한 논문이 드물고 후두엽과 측두 엽의 활성에 대해 보고한 기존 연구가 많지 않아 결과의 의 미를 해석하는 데 어려움이 있지만 중후두엽은 시각 정보 처리에 관여하고, 중측두엽은 정보의 인식, 의미 해석과 기 억될 사건의 처리에 관여한다고 알려져 있어(Furey 등 2013) 이번 연구를 통해 PTSD 환자군에서 감정 자극 시 외상과 관 련된 자극의 시각 정보 처리와 그에 대한 의미 해석과 관련 된 영역이 더욱 활성화되었다는 것을 유추해 볼 수 있었다.

정상 대조군과 PTSD 환자 그룹 간 비교 분석에서는 중성 자극하에서는 그룹 간 차이를 나타내지 않았으나 감정 자극 하에서는 PTSD를 가진 환자군에서 상전두이랑, 중전두이 랑, 보조 운동 영역, 상측두이랑, 중측두이랑, 모서리위이랑, 모이랑, 상후두이랑, 혀이랑 영역에서 정상 대조군에 비해 더 큰 대뇌 활성화를 나타내었다. 이전 PTSD 환자들의 기능 적 자기공명영상 연구에서 주로 전전두엽과 편도체의 활성
패턴의 이상을 보고하였는데 이번 실험결과에서는 전전두 엽의 활성 패턴의 변화는 나타내었으나 편도체에서는 유의 미한 활성 패턴의 변화를 나타내지 않았다. 실제 본 연구에 서는 PTSD 환자군으로 선정된 대상자들 모두가 지속적인 약물치료를 받고 있었으며 현재 우울장애를 비롯하여 다른 정신장애를 동반하지 않은 점이 편도체의 활성화 정도에 영 향을 미쳤을 것으로 생각된다.

정서와 인지의 상호작용은 등측 집행 체계(dorsal executive system)와 복측 정서 체계(ventral affective system)로 구 성되어 있으며 등측 집행 체계에는 등외측 전전두피질(dorsolateral prefrontal cortex, DLPFC) 및 외측 두정엽(lateral parietal cortex)을 포함하며 이러한 영역이 의식적인 작업기 억을 수행하는 데 있어 목적과 연관된 정보를 유지하는 데 필수적이다(Chafee와 Goldman-Rakic 2000). 반면 복측 정 서 체계에는 복외측 전전두피질(ventrolateral prefrontal cortex), 내측 전전두피질(medial prefrontal cortex)과 편도체 (amygdala)로 이루어져 있으며 감정 처리 과정에 필수적으로 알려져 있다(Courtney 등 1997). 본 연구의 실험결과로 보아 $\mathrm{PTSD}$ 환자군에서 $\mathrm{DLPFC}$ 에서의 활성 증가는 정신적 외상 과 관련된 무의식적인 감정 자극이 불안을 유발하고 이것이 의식적인 작업기억과 인지기능을 억제하는 부위를 활성화 시킨다는 것을 확인해 볼 수 있었다.

점차 외상후 스트레스장애 환자의 치료에 있어 정신역동 적인 접근을 포함한 심리적 치료와 신경생물학적 치료가 함 께 이루어지는 통합 치료의 중요성이 강조되고 있으나 정신 적 외상을 겪은 사람들에게 정신역동적 접근을 포함한 심리 적인 치료가 개념이 다소 추상적이며, 치료의 효과를 객관적 으로 입증하는 연구가 많지 않다는 등의 이유로 도외시하는 경향이 있어 왔다. 이러한 의미에서 본 연구는 정신적 외상 과 관련하여 무의식적인 감정 자극이 의식적인 작업기억, 인 지기능에 어떠한 영향을 주는지 확인해 봄으로써 정신적 외 상으로 파생되어 나타나는 무의식적인 감정 자극이 대뇌의 신경생물학적인 변화와 어떻게 연결되는지 확인해 보았으며 이러한 기초 자료로 향후 정신분석 및 정신치료 전후의 대뇌 활성의 변화와 신경정신분석(neuropsychoanalysis) 이론들 을 만드는 데 기초 자료로 이용될 수 있을 것이다.

이러한 신경정신분석에 대한 연구와 배움을 통해 정신분 석가는 치료 결정에 있어 좀 더 숙고할 수 있을 것이며 질환 의 생물학적인 토대에 대한 전체적인 조망을 가짐으로써 정 신분석적 정신치료가 좀 더 넓은 관점을 갖게 하고 환자에 게 치료에 대해 알려줄 수 있게 될 것이다. 심리적 충격의 후 유증에 대한 치료에 있어, 심리적인 기능의 변화뿐 아니라 뇌의 기능과 구조의 변화의 측면에서 영속적인 변화가 있을 
수 있다는 사실을 아는 것은 중요할 것이다(Beutel 등 2003).

본 연구의 제한점은 첫째, 머리의 움직임이나 fMRI 촬영 의 제한된 시간으로 인해 작업기억 수행 과제 실험이 몇 번 의 제한된 횟수로 이뤄진다는 것이다. 둘째, PTSD 실험군이 환자의 전체 특징을 대표하지 못한다는 점이다. 정상군과 환 자군의 총 표본 수가 20명으로 샘플 사이즈가 작을 수 있으 며 정상군과 환자군에 비교적 젊은 연령대만 포함되어 연구 결과의 일반화에 제한점이 있을 수 있다. 셋째, 약물 사용, 유 병 기간, 치료 기간 등의 임상적인 요인들이 충분히 통제되 지 않았으며 정상군에서는 MMSE나 CAPS 등의 scale의 평 가가 이뤼지지 않아 제한점으로 작용할 수 있을 것이다. 또 한 활성화 패러다임을 위해 사용된 감정 자극 사진에 외국인 의 얼굴이 포함되어 있으며 이러한 요인들이 작업기억 수행 이나 대뇌 활성화에 대한 영향에 교란변수로 작용할 수 있 다. 넷째, 기억 인출 단계에서 반응의 정확도나 반응 시간을 평가하게 되는데 2초 동안의 평가 시간이 너무 짧아 반응의 정확도에 영향을 미칠 수 있다는 점이다. 다섯째, 연구 설계 상 유년기 정신적 외상을 경험하지 않은 외상후 스트레스장 애 환자가 대조군에 포함되지 않아 대뇌 활성화의 결과가 유년기 정신적 외상에 의한 영향인지 단순 외상후 스트레스 장애 환자의 특성인지를 구분짓는 데에 한계가 있다는 점이 다. 마지막으로, 최종 분석에서 false discovery rate나 family wise error와 같은 multiple correction이 시행되지 않아 통 계적 제한점이 있을 수 있다.

이러한 제한점에도 불구하고 본 연구는 외상후 스트레스 장애 환자를 통해 무의식적 감정 자극과 의식적 작업기억의 상호작용으로 무의식적 감정이 일상 생활에 미치는 영향을 확인해 보았다는 점과 무의식적 감정 자극과 관련된 대뇌 영역 및 신경회로에 대해 알 수 있다는 데에 의의가 있었다. 감정 과정이 무의식에서 진행되며 불쾌한 감정을 피하기 위 해서 무의식적으로 방어한다는 점을 비추어 볼 때 정신분석 과정에 있어서도 무의식이 의식적인 활동, 작업 수행에 영향 을 주고 있다는 점을 확인하는 데에 본 연구의 의의가 있을 것이다. 이번 연구는 예비연구로 후속연구에서는 더 많은 표 본 수를 포함한 연구가 필요할 것이며, 이와 더불어 유년기 정신적 외상의 경험이 없는 외상후 스트레스장애 환자들에 대한 연구도 필요할 것으로 생각된다. 많은 수의 대상자를 통해 무의식과 관련된 불쾌한 감정이 실제 의식적인 작업 수행에 어떠한 신경 연결성을 가지고 있는지 확인할 수 있 을 것이며, 더 구체적이고 명확한 대뇌 활성화 영역을 확인 할 수 있을 것이다.

\section{Acknowledgments}

본 연구는 한국정신분석학회(Korean Association of Psychoanalysis) 연구비 및 한국연구재단(NRF-2019059029)의 지원을 받 아 수행되었음.

\section{Conflicts of Interest}

The authors have no potential conflicts of interest to disclose.

\section{Author Contributions}

Conceptualization: Jong-Chul Yang, Zoon-Sun Um, Jong-Il Park. Data curation: Zoon-Sun Um, Gwang-Won Kim, Jong-Chul Yang, Jong-Il Park. Formal analysis: Zoon-Sun Um, Jong-Chul Yang, Jong-Il Park. Funding acquisition: Jong-Chul Yang. Investigation: Zoon-Sun Um, Gwang-Won Kim, Jong-Chul Yang, Jong-Il Park. Methodology: Jong-Chul Yang, Zoon-Sun Um, Jong-Il Park. Project administration: Jong-Chul Yang, Jong-Il Park. Writing — original draft: Zoon-Sun Um, Jong-Chul Yang, Jong-Il Park. Writing — review \& editing: Zoon-Sun Um, Jong-Chul Yang, Jong-Il Park.

\section{ORCID iDs}

Jong-Chul Yang: https://orcid.org/0000-0002-7701-2718

Zoon-Sun Um: https://orcid.org/0000-0001-7511-0851

\section{REFERENCES}

Ablon J, Jones E. How expert clinicians' prototypes of an ideal treatment correlate with outcome in psychodynamic and cognitive-behavioral therapy. Psychotherapy Research 1998;8:71-83.

Baddeley AD, Andrade J. Working memory and the vividness of imagery. J Exp Psychol Gen 2000;129:126-145.

Bergouignan L, Chupin M, Czechowska Y, Kinkingnéhun S, Lemogne C, Le Bastard G, et al. Can voxel based morphometry, manual segmentation and automated segmentation equally detect hippocampal volume differences in acute depression? Neuroimage 2009;45:29-37.

Beutel ME, Stern E, Silbersweig DA. The emerging dialogue between psychoanalysis and neuroscience: neuroimaging perspectives. J Am Psychoanal Assoc 2003;51:773-801.

Blake DD, Weathers FW, Nagy LM, Kaloupek DG, Gusman FD, Charney DS, et al. The development of a clinician-administered PTSD Scale. J Trauma Stress 1995;8:75-90.

Bradley MM, Lang PJ. The International Affective Picture System (IAPS) in the study of emotion and attention. In: Coan JA, Allen JJB. Series in affective science. Handbook of emotion elicitation and assessment. New York, NY: Oxford University Press;2007. p.29-46.

Chafee MV, Goldman-Rakic PS. Inactivation of parietal and prefrontal cortex reveals interdependence of neural activity during memoryguided saccades. J Neurophysiol 2000;83:1550-1566.

Courtney SM, Ungerleider LG, Keil K, Haxby JV. Transient and sustained activity in a distributed neural system for human working memory. Nature 1997;386:608-611.

Curtis CE, D'Esposito M. The effects of prefrontal lesions on working memory performance and theory. Cogn Affect Behav Neurosci 2004; 4:528-539.

Davidson RJ, Irwin W. The functional neuroanatomy of emotion and affective style. Trends Cogn Sci 1999;3:11-21.

D'Esposito M, Postle BR, Jonides J, Smith EE. The neural substrate and temporal dynamics of interference effects in working memory as revealed by event-related functional MRI. Proc Natl Acad Sci U S A 1999;96:7514-7519.

Dolcos F, McCarthy G. Brain systems mediating cognitive interference by emotional distraction. J Neurosci 2006;26:2072-2079.

Dolcos F, Miller B, Kragel P, Jha A, McCarthy G. Regional brain differ- 
ences in the effect of distraction during the delay interval of a working memory task. Brain Res 2007;1152:171-181.

Dolcos F, Diaz-Granados P, Wang L, McCarthy G. Opposing influences of emotional and non-emotional distracters upon sustained prefrontal cortex activity during a delayed-response working memory task. Neuropsychologia 2008;46:326-335.

Furey ML, Drevets WC, Hoffman EM, Frankel E, Speer AM, Zarate CA. Potential of pretreatment neural activity in the visual cortex during emotional processing to predict treatment response to scopolamine in major depressive disorder. JAMA Psychiatry 2013;70:280290.

Gillies D, Taylor F, Gray C, O'Brien L, D'Abrew N. Psychological therapies for the treatment of post-traumatic stress disorder in children and adolescents (Review). Evid Based Child Health 2013;8:1004-1116.

Goldman-Rakic PS. The prefrontal landscape: implications of functional architecture for understanding human mentation and the central executive. Philos Trans R Soc Lond B Biol Sci 1996;351:1445-1453.

Hasegawa M, Miyata K, Abe Y, Ishigami T. Radiofrequency heating of metallic dental devices during 3.0 T MRI. Dentomaxillofac Radiol 2013;42:20120234.

Hendler T, Rotshtein P, Hadar U. Emotion-perception interplay in the visual cortex: "the eyes follow the heart." Cell Mol Neurobiol 2001; 21:733-752.

Horowitz MJ. Stress-response syndromes: a review of posttraumatic and adjustment disorders. Hosp Community Psychiatry 1986;37:241-249.

Kim GW, Chung YC, Yang JC, Chung GH, Park TJ, Jeong GW. Neuroanatomical mechanism on the effect of distraction in working memory maintenance in patients with schizophrenia. J Neuropsychiatry Clin Neurosci 2015;27:e1-e9.

Krystal H. Psychoanalytic views on human emotional damages, post traumatic stress disorder, psychological and biological sequelae. Washington, DC: American Psychiatric Association Publishing;1984. p.1-28.

Lanius RA, Williamson PC, Boksman K, Densmore M, Gupta M, Neufeld RW, et al. Brain activation during script-driven imagery induced dissociative responses in PTSD: a functional magnetic resonance imaging investigation. Biol Psychiatry 2002;52:305-311.

Martin A, Wiggs CL, Altemus M, Rubenstein C, Murphy DL. Working memory as assessed by subject-ordered tasks in patients with obsessive-compulsive disorder. J Clin Exp Neuropsychol 1995;17:786-792.

Oldfield RC. The assessment and analysis of handedness: the Edinburgh inventory. Neuropsychologia 1971;9:97-113.

Phan KL, Taylor SF, Welsh RC, Ho SH, Britton JC, Liberzon I. Neural correlates of individual ratings of emotional salience: a trial-related fMRI study. Neuroimage 2004;21:768-780.

Schuff N, Zhang Y, Zhan W, Lenoci M, Ching C, Boreta L, et al. Patterns of altered cortical perfusion and diminished subcortical integrity in posttraumatic stress disorder: an MRI study. Neuroimage 2011;54 Suppl 1:S62-S68.

Watts FN, MacLeod AK, Morris L. Associations between phenomenal and objective aspects of concentration problems in depressed patients. Br J Psychol 1988;79:241-250.

Westen $\mathbf{D}$. The scientific status of unconscious processes: is Freud really dead? J Am Psychoanal Assoc 1999;47:1061-1106. 